\title{
Effects of Supplementation of Amla (Emblica officinalis) Fruit Powder Meal on Growth Performance in Broiler Chickens
}

\author{
B. Naik ${ }^{1}$, K. Behera ${ }^{1 *}$, L. K. Babu ${ }^{1}$, K. Sethy ${ }^{2}$, S. M. Nanda ${ }^{3}$ and P. K. Pradhan ${ }^{1}$ \\ ${ }^{1}$ Department of Livestock Production and Management, College of Veterinary Science \& \\ Animal Husbandry, OUAT, Bhubaneswar-75100, India \\ ${ }^{2}$ Department of Animal Nutrition, College of Veterinary Science \& Animal Husbandry, \\ OUAT, Bhubaneswar-751003, India \\ ${ }^{3}$ Department of Veterinary \& Animal Husbandry Extension, College of Veterinary Science \& \\ Animal Husbandry, OUAT, Bhubaneswar-751003, India \\ *Corresponding author
}

\section{Keywords}

Amla fruit powder, Growth performance, Broiler chicken

Article Info

Accepted:

20 January 2020

Available Online:

10 February 2020
Poultry industry in India has emerged as one of the fastest growing segment of the agriculture sector, ranking sixth in broiler production with an annual output of 2.39 million tonnes of broiler meat. The consumers are now becoming more aware of safety and quality of food products consumed by them. Use of feed additives has become popular due to the absence of side effects unlike antibiotics. The present study was conducted taking 160 day old Vencobb broiler chickens and the experimental birds were divided into 4 groups (T1, T2, T3 and T4) with 2 replicate group of each, having 20 broiler chickens in every replicate in a complete randomized design.On $21^{\text {st }}$ day, the birds under $\mathrm{T} 1(0.5 \%$ level of amla fruit powder supplementation) showed the highest body weight $(829.55 \pm 11.41 \mathrm{~g})$, which was statistically significant ( $\mathrm{p}>0.05)$ as compared to $\mathrm{T} 1(778.53 \pm 12.34 \mathrm{~g})$, T3 $(798.32 \pm 13.07 \mathrm{~g})$ and T4 $(788.46 \pm 12.78 \mathrm{~g})$.Supplementation of Amla fruit powder@0.5\% level enhances the body weight and FCR without any adverse effect and at $1 \%$ and $2 \%$ level of inclusion the increase in body weight was found to be moderate. Therefore, this may prove to a feed additive that can be used in broiler feeds.

\section{Introduction}

Poultry industry in India has emerged as one of the fastest growing segment of the agriculture sector, ranking sixth in broiler production with an annual output of 2.39 million tonnes of broiler meat. The low productivity is mainly due to poor management, inadequate nutrition and health coverage. The consumers are now becoming more aware of safety and quality of food products consumed by them. The production 
of safer poultry products without any chemical and microbial residues is the order of the day. Feed additives are one of the important tools used for improving feed conversion ratio, growth rate and disease resistance etc. This has leads to widespread use of a number of "feed additives". Feed additives are commonly described as nonnutrient substances, which accelerate growth, efficiency of feed utilization, beneficial for health or metabolism of the animals (Church and Pond, 1988).

Use of antibiotics has negative effects on animal health and its production such as residues in tissues, withdrawal period and development of resistance in microorganisms (Botsoglou and Fletouris, 2001). Recently, the emphasis is being directed towards the search of herbal formulations, which could be effective for amelioration of stress and leads to increase in production of birds. Several
Indian herbs are reported to possess adaptogenic, anti-stress and immunemodulator properties (Wadhwa et al., 2007).

Among the non-conventional feeds, it was found that feeding of fish silage at 5\% level proves to be economical for growth of broiler Japanese quail (Mohanty et al., 2020).

\section{Materials and Methods}

A total number of 160 day-oldVencobbbroiler chickens (Gallus gallusdomesticus) were taken and the experimental birds divided into 4 groups with two replicate group of each, having 20 broiler chickens in every replicate in a complete randomized design. The chickens were weighed and transferred to experimental shed in the farm itself with standard management and healthcare practices. The dietary management were as follows:

\begin{tabular}{|l|l|}
\hline Groups & Dietary treatment \\
\hline $\mathbf{T}_{1}($ Control): & Basal Diet \\
\hline $\mathbf{T}_{2}:$ & Basal Diet $+\mathbf{0 . 5 \%}$ amlapowder \\
\hline $\mathbf{T}_{3}:$ & Basal Diet $+\mathbf{1 \%}$ amlapowder \\
\hline $\mathbf{T}_{4}:$ & Basal Diet $+\mathbf{2 \%}$ amlapowder \\
\hline
\end{tabular}

The amla used in this experiment was purchased fresh and washed. Then amla was sundried and was later ground into powder. The powdered amla was then sealed in polythene bag before incorporation into the feed. The proximate composition of amlafed to the birds as per Eevuri and Putturu (2013) is presented in Table 1. All the data generated in the above experiments were statistically analyzed using IBM SPSS 22.0. For comparison of groups, Generalized Linear Model, ANOVA procedure and Duncan's multiple range tests were used (Steel and Torrie, 1980)

\section{Results and Discussion}

The effect of feeding different levels of amla fruit powder on the body weight of the experimental birds is presented in Table 2 . There was no significant variation $(p>0.05)$ with respect to the mean day-old body weight and mean body weight on $7^{\text {th }}$ and $14^{\text {th }}$ day.

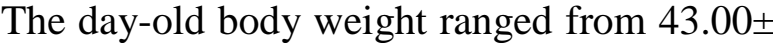
$1.48 \mathrm{~g}$ in $\mathrm{T} 1$ to $43.66 \pm 1.19 \mathrm{~g}$ in T3. On both $7^{\text {th }}$ and $14^{\text {th }}$ day, T2 birds had the highest body weight $152.33 \pm 2.79 \mathrm{~g}$ and $452.82 \pm 7.23 \mathrm{~g}$, respectively, though there was no statistical superiority. On $21^{\text {st }}$ day, the birds under T1 $(0.5 \%$ level of amla fruit powder 
supplementation) showed the highest body weight $(829.55 \pm 11.41 \mathrm{~g})$, which was statistically significant $(\mathrm{p}>0.05)$ as compared to $\mathrm{T} 1(778.53 \pm 12.34 \mathrm{~g}), \mathrm{T} 3(798.32 \pm 13.07$ g) and T4 (788.46 $\pm 12.78 \mathrm{~g})$. When the experimental birds attained $28^{\text {th }}$ day, the body weight of birds in $\mathrm{T} 2$ exhibited the highest body weight $\left(1424.33^{\mathbf{c}} \pm 19.37 \mathrm{~g}\right)$, which was significantly higher than the rest. Body weight of the birds under T3 and T4 were statistically comparable at $28^{\text {th }}$ day age (1355.65 \pm $18.94 v s .1317 .63 \pm 17.88 \mathrm{~g}$ ). At the end of the experiment on $35^{\text {th }}$ day, the birds from $\mathrm{T} 2 \mathrm{had}$ the highest body weight $(2019.26 \pm 20.19 \mathrm{~g})$, which was significantly higher $(p>0.05)$ than $\mathrm{T} 1, \mathrm{~T} 3$ and T4. At this age, the body weights of the experimental birds under $\mathrm{T} 3$ and $\mathrm{T} 4 \mathrm{did}$ not significantly $(1959.65 \pm 22.36 \mathrm{~g}$ vs. $1931.25 \pm 21.64 \mathrm{~g})$

The cumulative body weight gains of the experimental birds under different dietary treatments have been depicted in the Table 3 . The cumulative body weight gain up to second week (0-2 weeks) was significantly higher $(\mathrm{p}>0.05)$ in T2 $(409.82 \pm 4.94 \mathrm{~g})$ and T3 (405.50 $\pm 6.23 \mathrm{~g})$ as compared to T1 $(386.35 \pm 5.32)$ and $\mathrm{T} 4(392.76 \pm 5.85 \mathrm{~g})$ birds. The experimental birds under T2 group had significantly higher( $p>0.05)$ cumulative body weight gain up to third week $(786.55 \pm 11.09$ g) as compared to rest three treatment groups. Similar result was also observed for the cumulative body weight up to fourth week, where it was significantly maximum $(p>0.05)$ in T2 birds (1381.33 $\pm 15.64 \mathrm{~g}$ ), followed by T3 birds (1312.49 $\pm 16.46 \mathrm{~g})$, T3 (1273.97 \pm $15.43 \mathrm{~g})$ and lastly $\mathrm{T} 1(1245.98 \pm 13.88 \mathrm{~g})$. The highest cumulative body weight up to fifth week observed in T2 treatment group $(1976.26 \pm 19.28 \mathrm{~g})$, which was significantly higher $(p>0.05)$ than rest three groups. The higher body weights observed in amla supplemented groups may be attributed to anabolic and antioxidant effect of ascorbic acid, gallic acid and tannic acids present in $E$. officinalis(McDowell, 1989). Similar findings were reported by (Maini et al., 2007; Kumari et al., 2012; Patil et al., 2014).

The effect of supplementation of amla fruit powder on the weekly feed intake of the experimental birds under different treatment groups has been presented in Table 4 .

The weekly feed for the first week was comparable $(\mathrm{P}>0.05)$ in all the treatment groups ranging from $331.27 \pm 10.32 \mathrm{~g}$ (T1) to $345.15 \pm 9.47 \mathrm{~g}$ (T3). During the second week, birds from T2 group consumed significantly higher $(\mathrm{P}>0.05)$ feed when compared to $\mathrm{T} 1$ birds $(620.24 \pm 13.42 \mathrm{vs}$. $583.94 \pm 12.64 \mathrm{~g}$ ), but was not statistically different from T3 $(601.53 \pm 12.53 \mathrm{~g})$ and $\mathrm{T} 4$ $(600.63 \pm 11.29 \mathrm{~g})$ birds. During the third week of experiment, birds from T2 group showed significantly higher $(\mathrm{P}>0.05)$ feed consumption (785.84 $\pm 15.33 \mathrm{~g}$ ) as compared to rest three treatment groups. During fourth week, T3 birds had significantly higher $(\mathrm{P}>0.05)$ feed consumption (1051.69 \pm 17.07 g) followed by T1 and T2 $(977.77 \pm 16.49 \mathrm{~g}$ and $976.69 \pm 16.41 \mathrm{~g}$, respectively) and lastly the T2 birds $(898.90 \pm 16.89 \mathrm{~g})$. During the final week of the experiment i.e. the fifth week, the same trend continued where the T1 birds had significantly higher $(\mathrm{P}>0.05)$ feed consumption $(1085.81 \pm 13.93 \mathrm{~g})$ which was comparable with T4 birds (1080.68 $\pm 14.93 \mathrm{~g}$ ), but distinctly higher $(\mathrm{P}>0.05)$ than $\mathrm{T} 3(950.16$ $\pm 16.53 \mathrm{~g})$ and $\mathrm{T} 2(904.64 \pm 15.62 \mathrm{~g})$ birds.

Cumulative feed intake of the experimental birds after supplementation of amla fruit powder at different levels is illustrated in Table 5 .

Up to second week of the experimentation, cumulative feed intake was significantly higher $(\mathrm{P}>0.05)$ in $\mathrm{T} 2$ birds $(964.51 \pm 10.49$ $\mathrm{g})$, as compared to T1 (915.22 $\pm 14.68 \mathrm{~g})$, but similar to T3 (946.67 $\pm 14.74 \mathrm{~g})$ and T4 birds $(942.67 \pm 10.79 \mathrm{~g})$. The cumulative feed intake up to third week also showed 
significantly maximum intake by the $\mathrm{T} 2$ birds $(1750.35 \pm 18.31 \mathrm{~g})$ with respect to other three experimental groups. The trend continued for the cumulative feed intake up to fourth week, where the birds under T2 $(2649.25 \pm 20.14 \mathrm{~g})$ had distinctly higher feed intake in comparison to rest three treatment groups. But at the end of the experiment, the birds from $\mathrm{T} 1(3612.86 \pm 26.28 \mathrm{~g})$ and $\mathrm{T} 4$ $(3650.06 \pm 21.63 \mathrm{~g})$ had significantly higher cumulative feed intake as compared to T2 $(3553.89 \pm 20.19 \mathrm{~g})$ and T3 (3566.56 \pm 19.23 g) birds. The lower feed consumption at higher levels of amla supplemented group than control group might be due to better utilization of nutrients. Similar observations were made by Emadi and Kermanshaki (2006). The feed intake of all the chicks receiving amla fruit powder was lower than control and there was a linear decrease with the level of addition (Kumari et al., 2012). Similarly, decrease in feed consumption as above was also reported by (Wadhwa et al., 2007, andBisht et al., 2006) supplemented amla powder in broiler ration.

Cumulative FCR of the experimental birds in response to the supplementation of Amla fruit powder at different level of inclusion has been depicted in Table 6. Up to fourth week, FCR did not vary significantly among all the treatment groups, whereas at the end of the experiment FCR of T2 birds was found to be significantly superior compared to $\mathrm{T} 1$ birds $(1.76 \pm 0.06$ vs. $1.91 \pm 0.05)$. The performance of the birds under T3 and T4 birds did not vary statistically in comparison to either $\mathrm{T} 1$ or T2 groups. Similar observation has been noted by Rekhate et al., (2010). The feed intake of all the chicks receiving amla was lower than ofcontrol and there was a linear decrease with level of addition (Kumari et al., 2012)

Table.1 Composition of amlapowder (2.6 g)

\begin{tabular}{|l|l|}
\hline Moisture & $\mathbf{5 . 0 5}$ to $6.78 \%$ \\
\hline Fat & 0.23 to $0.59 \%$ \\
\hline Calcium & $79.6 \mathrm{mg}$ \\
\hline Phosphorous & $12.38 \mathrm{mg}$ \\
\hline Iron & $88.03 \mathrm{mg}$ \\
\hline Vitamin-C & $700 \mathrm{mg}$ \\
\hline
\end{tabular}

Table.2 Average weekly body weight $(\mathrm{g})$ of the experimental broiler birds under different dietary treatments

\begin{tabular}{|c|c|c|c|c|}
\hline Age & T1 & T2 (0.5\%) & T3 (1.0\%) & T4 (2.0\%) \\
\hline 0 day & $43.33 \pm 1.39$ & $43.00 \pm 1.48$ & $43.16 \pm 1.08$ & $43.66 \pm 1.19$ \\
\hline $\mathbf{7}^{\text {th }}$ day & $144.66 \pm 2.67$ & $152.33 \pm 2.79$ & $148.77 \pm 1.82$ & $146.17 \pm 2.03$ \\
\hline $\mathbf{1 4}^{\text {th }}$ day & $429.68 \pm 5.66$ & $452.82 \pm 7.23$ & $448.66 \pm 8.69$ & $436.42 \pm 6.96$ \\
\hline $\mathbf{2 1}^{\text {st }}$ day & $778.53^{\mathbf{a}} \pm 12.34$ & $829.55^{\mathbf{b}} \pm 11.41$ & $798.32^{\mathbf{a}} \pm 13.07$ & $788.46^{\mathbf{a}} \pm 12.78$ \\
\hline $\mathbf{2 8}^{\text {th }}$ day & $1289.31^{\mathbf{a}} \pm 17.13$ & $1424.33^{\mathbf{c}} \pm 19.37$ & $1355.65^{\mathbf{b}} \pm 18.94$ & $1317.63^{\mathbf{a b}} \pm 17.88$ \\
\hline $\mathbf{3 5}^{\text {th }}$ day & $1891.55^{\mathbf{a}} \pm 24.61$ & $2019.26^{\mathbf{c}} \pm 20.19$ & $1959.65^{\mathbf{b}} \pm 22.36$ & $1931.25^{\mathbf{a b}^{\mathbf{b}} \pm 21.64}$ \\
\hline
\end{tabular}

*Means bearing different superscripts differ significantly along the rows 
Table.3 Average cumulative body weight gain (g) of the experimental birds under different dietary treatments

\begin{tabular}{|c|c|c|c|c|}
\hline Week & T1 & T2 & T3 & T4 \\
\hline $0-1$ & $101.33 \pm 2.89$ & $109.33 \pm 3.22$ & $105.61 \pm 4.08$ & $102.51 \pm 3.77$ \\
\hline $0-2$ & $386.35^{\mathrm{a}} \pm 5.32$ & $409.82^{\mathrm{b}} \pm 4.94$ & $405.50^{\mathrm{b}} \pm 6.23$ & $392.76^{\mathrm{a}} \pm 5.85$ \\
\hline $0-3$ & $735.20^{\mathrm{a}} \pm 9.11$ & $786.55^{\mathrm{b}} \pm 11.09$ & $755.16^{\mathrm{a}} \pm 14.67$ & $744.80^{\mathrm{a}} \pm 13.36$ \\
\hline $0-4$ & $1245.98^{\mathrm{a}} \pm 13.88$ & $1381.33^{\mathrm{c}} \pm 15.64$ & $1312.49^{\mathrm{b}} \pm 16.46$ & $1273.97^{\mathrm{a}} \pm 15.43$ \\
\hline $0-5$ & $1848.22^{\mathrm{a}} \pm 17.59$ & $1976.26^{\mathrm{c}} \pm 19.28$ & $1916.49^{\mathrm{b}} \pm 18.71$ & $1887.59^{\mathrm{ab}} \pm 20.32$ \\
\hline
\end{tabular}

*Means bearing different superscripts differ significantly along the rows.

Table.4 Average weekly feed intake (g) of the experimental broiler birds under different dietary treatments

\begin{tabular}{|c|c|c|c|c|}
\hline Week & T1 & T2 & T3 & T4 \\
\hline $\mathbf{1}^{\text {st }}$ week & $331.27 \pm 10.32$ & $344.27 \pm 8.79$ & $345.15 \pm 9.47$ & $342.04 \pm 10.08$ \\
\hline $\mathbf{2}^{\text {nd }}$ week & $583.94^{\mathbf{a}} \pm 12.64$ & $620.24^{\mathbf{b}} \pm 13.42$ & $601.53^{\mathbf{a}} \pm 12.53$ & $600.63^{\mathbf{a}} \pm 11.29$ \\
\hline $\mathbf{3}^{\text {rd }}$ week & $634.06^{\mathbf{a}} \pm 14.38$ & $785.84^{\mathbf{b}} \pm 15.33$ & $618.03^{\mathbf{a}} \pm 16.76$ & $650.02^{\mathbf{a}} \pm 15.88$ \\
\hline $\mathbf{4}^{\text {th }}$ week & $977.77^{\mathbf{b}} \pm 16.49$ & $898.90^{\mathbf{a}} \pm 16.89$ & $1051.69^{\mathbf{c}} \pm 17.07$ & $976.69^{\mathbf{b}} \pm 16.41$ \\
\hline $\mathbf{5}^{\text {th }}$ week & $1085.81^{\mathbf{b}} \pm 13.93$ & $904.64^{\mathbf{a}} \pm 15.62$ & $950.16^{\mathbf{a}} \pm 16.53$ & $1080.68^{\mathbf{b}} \pm 14.93$ \\
\hline
\end{tabular}

*Means bearing different superscripts differ significantly along the rows.

Table.5 Cumulative feed intake (g) of the experimental broiler birds under different dietary treatments

\begin{tabular}{|c|c|c|c|c|}
\hline Week & T1 & T2 & T3 & T4 \\
\hline $\mathbf{0 - 1}$ & $331.27 \pm 10.23$ & $344.27 \pm 8.34$ & $345.15 \pm 11.41$ & $342.04 \pm 8.32$ \\
\hline $\mathbf{0 - 2}$ & $915.22^{\mathbf{a}} \pm 14.68$ & $964.51^{\mathbf{b}} \pm 10.49$ & $946.67^{\mathbf{a}} \pm 14.74$ & $942.67^{\mathbf{a}} \pm 10.79$ \\
\hline $\mathbf{0 - 3}$ & $1549.27^{\mathbf{a}} \pm 19.43$ & $1750.35^{\mathbf{b}} \pm 18.31$ & $1564.71^{\mathbf{a}} \pm 17.26$ & $1592.69^{\mathbf{a}} \pm 15.87$ \\
\hline $\mathbf{0 - 4}$ & $2527.05^{\mathbf{a}} \pm 23.59$ & $2649.25^{\mathbf{b}} \pm 20.14$ & $2616.40^{\mathbf{a}} \pm 18.47$ & $2569.38^{\mathbf{a}} \pm 17.08$ \\
\hline $\mathbf{0 - 5}$ & $3612.86^{\mathbf{b}} \pm 26.28$ & $3553.89^{\mathbf{a}} \pm 20.19$ & $3566.56^{\mathbf{a}} \pm 19.23$ & $3650.06^{\mathbf{b}} \pm 21.63$ \\
\hline
\end{tabular}

*Means bearing different superscripts differ significantly along the rows.

Table.6 Cumulative Feed Conversion Ratio (FCR) of the experimental broiler birds under different dietary treatments

\begin{tabular}{|c|c|c|c|c|}
\hline Week & T1 & T2 & T3 & T4 \\
\hline $\mathbf{0 - 1}$ & $2.29 \pm 0.02$ & $2.26 \pm 0.03$ & $2.32 \pm 0.04$ & $2.34 \pm 0.06$ \\
\hline $\mathbf{0 - 2}$ & $2.13 \pm 0.04$ & $2.13 \pm 0.05$ & $2.11 \pm 0.02$ & $2.16 \pm 0.05$ \\
\hline $\mathbf{0 - 3}$ & $1.99 \pm 0.03$ & $2.11 \pm 0.06$ & $1.96 \pm 0.03$ & $2.02 \pm 0.05$ \\
\hline $\mathbf{0 - 4}$ & $1.96 \pm 0.06$ & $1.86 \pm 0.05$ & $1.93 \pm 0.04$ & $1.95 \pm 0.04$ \\
\hline $\mathbf{0 - 5}$ & $1.91^{\mathbf{b}} \pm 0.05$ & $1.76^{\mathbf{a}} \pm 0.06$ & $1.82^{\mathbf{a}} \pm 0.06$ & $1.89^{\mathbf{a}} \pm 0.03$ \\
\hline
\end{tabular}

$*$ Means bearing different superscripts differ significantly along the rows 
It can be concluded from our study that supplementation of Amla fruit powder @ $0.5 \%$ level enhances the body weight and FCR without any adverse effect and at $1 \%$ and $2 \%$ level of inclusion the increase in body weight was found to be moderate. Therefore, this can be included in the feed of the broiler chickens to observe increase in growth.

\section{References}

Bisht, K., Singh, S.K., Sharma, R.K., Pant, D. and Kumar, S. 2006. Effect of dietary supplementation of herbal liver stimulant on the performance of commercial broiler. Indian J. Sci.,41(3): 309-312

Botsoglou and Fletouris 2001. Drug residues in foods: pharma., food safety, and analysis

Church DC and Pond WG. 1988. Basic animal nutrition and feeding,John Wiley and Sons. Inc.United States of America.

Eevuri TR and Putturu R. 2013. Use of certain herbal preparations in broiler feeds-A review. Veterinary World,6(3).

Emadi, M. and Kermanshahi, H. 2006. Effect of turmeric rhizome powder on performance and carcass characteristics of broiler chickens. Int. J. Poult. Sci., 5(11): 1069-1072

Kumari, M., Wadhwa, D., Sharma, V.K. and Sharma, A. 2012. Effect of Amla (Emblica officinalis) pomace feeding on growth performance of commercial broilers. Indian J. Anim. Nutr., 29(4): 388-392.

Maini S, Rastogi SK, Korde JP, Madan AK and Shukla SK. 2007. Evaluation of Oxidative Stress and its Amelioration through Certain Antioxidants in Broilers during Summer, The Journal of Poultry
Science, 44(3):339-347

Mcdowell, L.R. 1989. Editor: Vitamins in Animal Nutrition. Comparative Aspects to Human Nutrition. Vitamin A and E. Academic Press London. P: 93-131.

Mohanty, A., L. K. Babu, B. Sahoo and Nanda, S. M. 2020. To Economize the Feed Cost of Broiler Japanese Quail (Coturnixcoturnix japonica) by Feeding Fish Silage. Int.J.Curr.Microbiol. App.Sci. 9(01): 722-726.

Patil AS, Wankhede SM and Kale VR. 2014. Effects of Emblicaofficinalis (amla) and vitamin $\mathrm{E}$ addition in diet on growth performance of broiler chickens reared under nutritional stress, Indian journal of animal nutrition, 31(4): 389-392

Rekhate, D.H., Ukey, S., Mangle, L.N. and Deshmukh, B.S. 2010. Effect of dietary supplementation of Shatavari (Asparagus racemosus wild) on heamato-biochemical parameters of broilers. Indian J. Poult. Sci., 34(3): 327-331

SPSS (Statistical Procedures for Social Sciences) 2019.SPSS User's guide version 22.0.SPSS Institute Inc., Cary $\mathrm{NC}$

Steel, R.G.D. and Torrie, J.H. (1980) Principles and procedures of statistics. A biometrical approach, 2nd Edition, McGraw-Hill Book Company, New York

Wadhwa D, Sood S, Meena K, Sharma VK and Chounan JS. 2007, Effect of supplementation of gooseberry (Emblica officinalis) powder supplementation on biological performance ofcommercial broilers. XXIV Annu. Conf. of IPSA and National Symposium 25-27 April 2007. Ludhiana: 95. 


\section{How to cite this article:}

Naik. B, K. Behera, L. K. Babu, K. Sethy, S. M. Nanda and Pradhan. P. K. 2020. Effects of Supplementation of Amla (Emblicaofficinalis) Fruit Powder Meal on Growth Performance in Broiler Chickens. Int.J.Curr.Microbiol.App.Sci. 9(02): 2805-2811. doi: https://doi.org/10.20546/ijcmas.2020.902.319 